\title{
A Comparative Analysis of the Determinants of State Reproductive Healthcare Policies
}

\author{
Vivian W. Greentree, John R. Lombard, and John C. Morris
}

This paper is a state comparative analysis of the determinants of a state's policies towards reproductive healthcare. While much of the literature focuses solely on abortion, our analysis employs a more comprehensive measure of access to reproductive healthcare. Three explanationsreligious, socioeconomic, and political — are tested to see which has the most significant impact on a state's likeliness to enact restrictive policies towards reproductive healthcare. We find that the political model is the best predictor of the level of state restrictiveness, and that the percent of women in the legislature is the most powerful variable. Combining the most significant variables from the three previous models into a single model, we find that the percent of women in the legislature, per capita income, and Democratic party control of the state House are the most influential predictors of variation in state restrictiveness towards abortion and reproductive healthcare policies. Lastly, we suggest several avenues for future research.

The U.S. Supreme Court's 1973 decision in Roe $v$ Wade set forth the precedent that a woman's constitutional right to privacy included her right to terminate a pregnancy. Subsequently, both the Webster v. Reproductive Health Services and Planned Parenthood of Southeastern Pennsylvania v. Casey decisions have allowed individual states more autonomy in enacting legislation which restricts or regulates abortion within their borders. In the 1989 Webster decision, the Supreme Court upheld a Missouri statute that prohibited the use of public facilities or personnel to provide abortion services (492, U.S. 490). Likewise, the Casey decision in 1992 again extended a state's authority to regulate or restrict abortion, abandoning the strict scrutiny standard set forth in Roe, and introducing the "undue burden" standard that is currently used (505, U.S. 833). As a result of these decisions the policy focus has shifted from the federal to the state level with state statutes being largely responsible for regulating reproductive health policies. For example, in 1991, 15 states were enforcing parental involvement laws (Oakley 2003). By 2005, 44 states had enacted legislation mandating either parental notice or consent, nine of which have been found to be unconstitutional and unenforceable (NARAL 2006). Additionally, in 2005, state legislatures considered 614 restrictive bills, with every state considering at

VIVIAN W. GREENTREE is a doctoral student at Old Dominion University. JOHN R. LOMBARD is assistant professor of public administration at Old Dominion University. JOHN C. MORRIS is associate professor public administration at Old Dominion University.

The American Review of Politics, Vol. 32, Winter, 2011-2012: 281-299

(c)2011 The American Review of Politics 
least one restrictive policy with the exception of the District of Columbia (NARAL 2006). Of these, fifty-eight restrictive policies were enacted. West Virginia considered 79 measures, the highest number of restrictive measures considered by any one state.

South Dakota, however, led the nation in actually enacting restrictive measures by passing six new prohibitive laws, including one that would take effect should Roe ever be overturned. That particular law, referred to as a trigger law, “... enacted a ban on abortion throughout pregnancy, with no exception for women who become pregnant due to rape or incest, or for women whose health would be threatened by continuing pregnancies" and allows abortion only if the woman's life is at risk (NARAL 2006).

Since most reproductive healthcare policy is now made at the state level, it is important to understand what influences each state to enact the policies it does. The literature in this area highlights the complex nature of the issue with researchers who have all focused on different explanations in attempts to explain both attitudes and the legislation that it produces related to reproductive healthcare policies. Since Roe there have been studies that attempt to answer questions like: Does public opinion or partisan make-up of the government determine state reproductive health policy? Is it a mixture? Do socioeconomic and demographic factors contribute to public opinion? How does public opinion on abortion translate into public policy? Does religion trump everything else? Researchers have examined these questions trying to determine exactly the extent to which these factors determine a state's likeliness of producing restrictive abortion policy. Several researchers since the Webster decision have attempted to predict the states that, should Roe $v$ Wade be overturned, would be most likely restrict access to abortion (Conway and Butler 1992; Gohmann and Ohsfeldt 1994). However, to our knowledge, no researchers have examined the broader policies concerning state restrictiveness towards reproductive healthcare.

This paper investigates the role various factors play in explaining the variation in state reproductive health policies. These factors are grouped into religious, socioeconomic, and political explanations. Using regression modeling, we attempt to determine which of these factors are the most important in explaining how restrictive a state will be in the area of reproductive healthcare. We also offer a revised "model of best fit" in pursuit of a more general explanation of state restrictiveness. Previous studies have analyzed some of these variables, but not within the comprehensive framework provided here. More importantly, those studies only analyzed abortion policy and not the wide-ranging area of reproductive healthcare in general. This analysis's dependent variable, The NARAL scorecard, is a comprehensive indicator of general reproductive healthcare, spanning from aspects like contraception access and state self-conscience clauses to insurance 
prohibition for abortion and trigger laws, aspects which encompass more than just abortion access and include a state's tendencies towards reproductive healthcare as a whole. This study's contribution is to include part of this broader concept of abortion and reproductive healthcare policy as a holistic view towards individual state dispositions rather than the singular research point of abortion policy. The research question we seek to answer is as follows: what factors best explain the level of restrictiveness of state reproductive health policy?

\section{The Dependent Variable}

The dependent variable in this study is the state's restrictiveness towards reproductive health policies. The ranking system, from the NARAL Pro-Choice America (NARAL) 2006 Report Card, adds points for restrictions on abortion and other aspects of reproductive health care and subtracts points for liberalizing laws. The system NARAL utilizes also takes into account the severity of laws and whether or not they are enforced (rather than those that courts have declared invalid). The NARAL index assigns point values to states based on their restrictive policies (i.e., Louisiana is ranked as one and has the most restrictive reproductive healthcare policies in place).

It is important to note that each state is assigned a numerical ranking based on policies already in place that affect access to reproductive health. The policies examined and ranked for 2005 are: abortion bans, biased counseling and mandatory delays, counseling ban/gag rules, access to emergency contraception, the Freedom of Choice Act, spousal consent/notice laws, insurance coverage for contraception, insurance prohibition for abortion, legislative declarations, trigger laws, physician-only restrictions, postviability restrictions, protection against clinic violence legislation, public facilities and public employees restrictions, refusals to provide medical services (i.e., abortion, contraception, family planning/birth control, sterilization, individual health care instructions, or prescriptions), restrictions on low-income and young women's access to abortions, Targeted Regulation of Abortion Providers (TRAP) laws, and whether or not the state had codified the protection of the right to choose in its state constitution.

NARAL has long been a source for information in the area of reproductive healthcare policy and though the organization takes a pro-choice stance in its lobbying efforts, their compilation of comprehensive state-level data in the field of reproductive healthcare has been seen as a resource by scholars, who have repeatedly utilized the organization's facts and figures (see Gohmann and Ohsfeldt 1994; Haas-Wilson 1996; Kahane 1994; Medoff 2002; Oakley 2003; Wetstein and Albritton 1995). NARAL's ordinal rank 
score indicator has been previously employed by Gohmann and Ohsfeldt (1994) who attempted to predict which states would restrict abortion and compared their results with NARAL's ranking. They found NARAL's ranking correctly classified states 87 percent of the time; their own model using abortion legislation predicted correctly 75 percent of the time. Wetstein and Albritton (1995) utilized the ranking structure in their attempts to understand the effects of public opinion on abortion policies. They concluded public preferences did have profound consequences on both abortion policy and access to abortion providers within a state. However, these previous studies are more limited in scope than the present study, and we provide both a more comprehensive model of understanding what makes a state more likely to enact restrictive reproductive healthcare policies and a more focused direction for future research. Moreover, the present analysis utilizes the raw point scores for each state, rather than an ordinal ranking.

Table 1 compares the Gohmann and Ohsfeldt (1994) rankings and the NARAL (2006) rankings. The Gohmann and Ohsfeldt (1994) ranking was the last academic study aimed at capturing and comparing the pro-choice/ anti-choice culture of individual states. And, while some differences may be accounted for by shifts in public and legislative preferences over time within states, the authors also attribute the variations in state rankings to the comprehensive model utilized by NARAL during their scoring process. NARAL's inclusion of aspects like availability of emergency contraception, general conscious clauses (in which medical professionals can refuse to write prescriptions, provide services, instructions or referrals, etc.) and access of low-income women to family planning funding through the state provide a broader sense of the state's predilection towards reproductive healthcare policy in general.

A Pearson Correlation test was run between Gohmann and Ohsfeldt's (1994) ranking structure and NARAL's ranking structure. The correlation between the two was, $\mathrm{r}=0.611(50), p$ (two-tailed) $<.05$. The authors interpret this result to show that the two variables are related, but not overly so. NARAL's ranking structure is much more comprehensive in nature than Gohmann and Ohsfeldt's (1994) primary focus on abortion policy.

\section{Three Models of State Restrictiveness}

The independent variables in this study are grouped into three categories: religious, socioeconomic, and political. Previous literature suggests these explanations highlight much of the variance between legislative outcomes in different states with regard to abortion policy. We draw on the previous works to build our models for analysis. 
Table 1. Comparison of Rankings

\begin{tabular}{lrrlrr}
\hline State & $\begin{array}{c}\text { G\&O Study } \\
\text { Ranking }\end{array}$ & $\begin{array}{c}\text { NARAL } \\
\text { Ranking }\end{array}$ & State & $\begin{array}{c}\text { G\&O Study } \\
\text { Ranking }\end{array}$ & $\begin{array}{r}\text { NARAL } \\
\text { Ranking }\end{array}$ \\
\hline Alabama & 14 & 10 & Montana & 39 & 28 \\
Alaska & 5 & 40 & Nebraska & 8 & 11 \\
Arizona & 15 & 34 & Nevada & 34 & 42 \\
Arkansas & 19 & 18 & New Hampshire & 2 & 29 \\
California & 44 & 50 & New Jersey & 17 & 32 \\
Colorado & 41 & 35 & New Mexico & 20 & 36 \\
Connecticut & 40 & 48 & New York & 43 & 41 \\
Delaware & 48 & 30 & North Carolina & 26 & 44 \\
Florida & 25 & 43 & North Dakota & 4 & 14 \\
Georgia & 36 & 33 & Ohio & 28 & 5 \\
Hawaii & 49 & 45 & Oklahoma & 13 & 22 \\
Idaho & 3 & 17 & Oregon & 46 & 47 \\
Illinois & 21 & 25 & Pennsylvania & 9 & 4 \\
Indiana & 12 & 19 & Rhode Island & 30 & 20 \\
Iowa & 16 & 24 & South Carolina & 27 & 9 \\
Kansas & 23 & 27 & South Dakota & 22 & 13 \\
Kentucky & 6 & 16 & Tennessee & 18 & 23 \\
Louisiana & 10 & 1 & Texas & 35 & 26 \\
Maine & 31 & 37 & Utah & 1 & 2 \\
Maryland & 47 & 39 & Vermont & 38 & 46 \\
Massachusetts & 42 & 38 & Virginia & 37 & 31 \\
Michigan & 32 & 6 & Washington & 50 & 49 \\
Minnesota & 24 & 15 & West Virginia & 45 & 7 \\
Mississippi & 33 & 8 & Wisconsin & 29 & 12 \\
Missouri & 11 & 3 & Wyoming & 7 & 21 \\
\hline
\end{tabular}

\section{Religious Explanations}

Religion has consistently been found to be an important predictor of abortion attitudes (Jelen and Wilcox 2003). The Catholic Church has had a long-standing opposition to abortion dating back to Pope Pius IX's revision of Canon Law to include excommunication for those who had abortions (Legge 1983). Evangelical Protestants are also less likely to support abortion rights than their Jewish and secular counterparts (Jelen and Wilcox 2003). In 1989 The New York Times carried an "Open Letter to Those Who Would Outlaw Abortion" taken from the excerpts of testimony given in Senate hearings by the Executive Director of the American Jewish Congress. In it, the Jewish leadership's position laid out their spiritual reasoning for supporting abortion rights, stating, "These religious traditions believe that the 
sacredness of life requires in some circumstances that the woman's wellbeing takes precedence over that of the fetus" ("Open Letter" 1989).

Blake and Del Pinal (1981), through analyzing groups who supported or opposed abortion in all circumstances, highlighted the significance of religious variables when compared to others. They concluded that abortion is primarily a religious issue, not based on class or gender. And, there is evidence reflecting organized religions' attempts to mold legislation to restrict abortion (Byrnes and Segar 1992). In 1976, shortly after the Roe v. Wade decision in 1973, representatives from the Roman Catholic Church, which was active in attempts to keep abortion illegal, testified in a Congressional hearing that they would mobilize their constituencies in efforts to attain a constitutional amendment to overturn the Roe decision (Evans 2002). Additionally, Evans (2002) reveals, organizations like the Christian Coalition and Concerned Women for America, who both actively denounce abortion, draw supporters from evangelical populations while the Roman Catholic Church has created the Right to Life Committee to organize local members and lobby for anti-abortion legislation. Therefore, states with a strong Catholic or evangelical presence can provide robust support for restrictive abortion policies. Cook et al. (1993) note that a strong Roman Catholic presence in a state could provide support for more restrictive abortion policies, but it could also mobilize the pro-choice segments of the population. They do not find the same counter-mobilization in response in states with a strong evangelical presence, leading them to wonder if perhaps the organizational strength of the Catholic Church and its parishes accounts for the difference (see also Norrander and Wilcox 1999). In a 2005 article which discussed a Catholic legislator's religious duty, Heft wrote, "Therefore, it is not sufficient for U.S. Catholic legislators to say about abortion only that they are personally opposed to it; they are also obliged to find ways, even while supporting the current legislation that protects the constitutional right of women to abortion, to lessen the number of abortions, if not eliminate them completely" (p. 270).

\section{The Hypothesized Impact of Religious Variables}

Religion variables are measured as the percent of Catholic, Evangelical, and Jewish faiths in the population of each state. It is expected that higher percent of Catholics and Evangelicals will produce more restrictive policies towards reproductive healthcare and that higher percent of Jewish population will produce less restrictive policies. Our specific hypotheses for testing are:

$\boldsymbol{H}_{1}$ : The higher the percentage of the Catholic population, the more restrictive a state will be towards reproductive healthcare. 
$\boldsymbol{H}_{2}:$ The higher the percentage of the Evangelical population, the more restrictive a state will be towards reproductive healthcare.

$\boldsymbol{H}_{3}$ : The higher the percentage of the Jewish population, the less restrictive a state will be towards reproductive healthcare.

\section{Socioeconomic Explanations}

The literature demonstrates that socioeconomic factors have a significant influence on state policies. States with better educated, wealthy populations tend to spend more on welfare and social programs and have a more liberal policy culture, which includes fewer restrictions on abortion (Wetstein and Albritton 1995). Additionally, Wetstein and Albritton (1995) and others (Hanson 1980) have shown that states with large metropolitan populations have less restrictive abortion policies. Strickland and Whicker (1992) attributed this phenomenon to the idea that urban areas attract working professionals who are heterogeneous. This diversity may enhance progressive and pro-choice attitudes. Conversely, rural areas are seen to be more homogeneous which may depress such diversity. Strickland and Whicker (1992) also found that per capita income was a significant predictor for a state's restrictiveness towards abortion post-Webster. The higher the average per capita income, the authors posited, the more pro-choice attitudes that are prevalent in the population, and the more liberal are policies enacted towards abortion. Greater general affluence of a state is also correlated with greater urbanization (Strickland and Whicker 1992), which is also seen to enhance pro-choice attitudes. Wetstein and Albritton's (1995) study confirmed that socioeconomic factors play a powerful indirect role on the abortion policies a state enacts.

Jelen and Wilcox (2003) reviewed the causes and consequences of public attitudes towards abortion and highlighted three demographic trends in attitudes towards abortion that have shifted over time. They noted the decline in correlation between education and support for abortion rights. Education, throughout most of the 1970's and 1980's, had been one of the strongest demographic indicators of support for abortion rights. They cited a drop in correlation between education and support for abortion rights throughout the 1990's, almost exclusively confined to Republicans.

In a 2000 abortion surveillance report the CDC reported that approximately 55 percent of women who attained legal abortions were white, 35 percent were black, and seven percent were of other races. Three percent were unknown. However, the abortion rate for black women (30 per 1,000 women) was 3.1 times the rate for white women (10 per 1,000 women). And the ratio for women of other races was 2 times the rate for white women (22 per 1,000 women). For Hispanics the abortion rate was 16 per 1,000. 
Previous literature analyzing race has been somewhat paradoxical. While white women have been found less likely to attain an abortion, in general whites have been found to be more approving of abortion rights for women (Strickler and Danigelis 2002). However, Strickland and Whicker (1992) found the literature to be inconclusive on black attitudes towards abortion and their own results found that the black population had no effect on abortion restrictiveness. However, they did find that states with a larger Hispanic population were more likely to have liberal abortion policies in place. Given the uncertain nature of the literature combined with the higher rates of abortion in blacks and Hispanics, the authors take the view that the higher percentage of blacks and Hispanics in the population, the less restrictive the state is towards reproductive healthcare.

\section{The Hypothesized Impact of Socioeconomic Variables}

Socioeconomic variables include race, ethnicity, average per capita income for the state, educational attainment, and the percentage of the population living in urban areas. Because per capita income and educational attainment are highly correlated, we use per capita income as our socioeconomic indicator. It is expected that the higher the percentage of the black and Hispanic population, the less restrictive the policies will be. It is expected that the higher percentage of the population that lives in urban areas and the higher the average per capita income, the less likely a state is to enact restrictive reproductive healthcare policies. Our specific hypotheses are:

$\boldsymbol{H}_{4}:$ The higher the percentage of the black population, the less restrictive a state will be towards reproductive healthcare.

$\boldsymbol{H}_{5}$ : The higher the percentage of the Hispanic population, the less restrictive a state will be towards reproductive healthcare.

$\boldsymbol{H}_{6}:$ The higher the per capita income, the less restrictive a state will be towards reproductive healthcare.

$\boldsymbol{H}_{7}:$ The higher the percentage of the metropolitan population, the less restrictive a state will be towards reproductive healthcare.

\section{Political Explanations}

Numerous studies have supported the link between public policies and constituents' ideological preferences. The 1980's saw a growing divide between the two national parties on the abortion issue, with the 1988 presidential election providing perhaps the most illustrative example. The Democratic national platform supported women's rights of reproductive freedom regardless of ability to pay for an abortion while the Republican national 
platform declared an unborn child has a fundamental right to life which may not be infringed upon (Strickland and Whicker 1992). The Republican national platform also called for the elimination of funding for those organizations that advocated or supported abortion rights. Some researchers have found abortion to be a bimodal issue (Medoff et al. 1995; Medoff 2002; Strickland and Whicker 1992) — one that can potentially cut across party lines to reflect basic socioeconomic, class, and religious differences. Strickland and Whicker's (1992) research indicated that political variables were more important in the post-Webster era. These findings are further supported by Baker et al. (1981), who found no relationship between political party affiliation and attitude. Yet after Webster, when states had more power in making abortion policy, evidence suggests a higher correlation between political party and attitudes on abortion. It follows then that factors like party control of political institutions and policy culture of a state are important predictors of state abortion policies (Norrander and Wilcox 1999).

More recent studies support a greater impact of political partisanship on how a legislator will vote on issues surrounding reproductive health. Kahane's (1994) empirical evidence on governors' positions on abortion supports this analysis as well. He finds that the position a governor takes on abortion is significantly influenced by their ideology, as well as demand from the public. However, when he compares this finding with state senates and state houses he notices that as the constituency becomes narrower, the ideology of the policy maker becomes somewhat less important in defining abortion position. As Kahane (1994) suggests, this change could be because of a cost-benefit evaluation on the part of the legislator. A legislator will analyze how many votes are lost or won by voting for or against abortion policies rather than relying solely on party ideology. Interpreting these results as inconclusive, Schecter (2001) engaged in another study comparing partisanship and religion influences and found that partisanship, gender, and legislator religion (for Catholics and Jewish members only) all are significant predictors of how a legislator will vote on abortion policy. In the same study of the Florida House of Representatives, he also found that party partisanship plays a larger role than constituency characteristics. This finding is contradictory to some more recent "morality policy" literature which posits that constituency and not legislator ideology and partisanship determines a state's policies towards abortion - or at the very least haves equal influence (Kahane 1994). Schecter (2001) suggests that further research in this area could bring about a reevaluation of "... whether or not the abortion issue is driven by public attitudes and constituent concerns" (p. 77).

If the ideology of legislators is indeed important to explaining the relative restrictiveness of a state's reproductive policies, we would expect that states in which government ideology is more conservative, reproductive 
rights for women will be more restrictive than in states where government ideology tends to be more liberal. This hypothesis may be tempered, however, by the degree of inter-party competition present in a state. Still, the literature clearly supports the idea that Democratic state legislatures produce more liberal abortion policy (Medoff 2002; Norrander and Wilcox1999).

Moreover, several recent studies analyze the effect women legislators have on abortion policy (Berkman and O'Conner 1993; Caiazza 2004; Medoff 2002; Norrander and Wilcox 1999). Norrander and Wilcox (1999) concluded that the more women there are in a legislature, the more likelihood of liberal abortion policies. They also found that women legislators are more likely to resist passing parental consent laws. Schecter (2001) found that being a male legislator reduced the chance of voting for liberal abortion policies by 25 percent and increased the chance of voting for greater restrictions for abortion by 21 percent. Medoff (2002) found that a state's abortion policy is largely determined by the strength of advocacy groups and political forces. His research showed the greater the membership of NARAL, percentage of female state legislators and percentage of Democratic female legislators, the less restrictive a state's abortion policy would be. Caiazza (2004) found that while Democratic women legislators were a stronger indicator for the advancement of women-friendly policies (including more liberal reproductive health policies), women in executive level state-wide offices and Republican women legislators were also important. Her conclusion, which is supported by the literature, was "having women in elected office cannot guarantee better policy for women, but it clearly helps" (p. 60).

We use a state's restrictiveness in its TANF program as a measure of a state's liberal policy culture. Under TANF, states are allowed to set the restrictiveness of their program sanctions within a set of federal guidelines (see Soss et al. 2001). Among those sanctions is the ability to set a "family cap" on recipients, which provides a disincentive for women receiving TANF benefits to bear additional children. Because TANF is a policy that primarily affects women, and because the family cap provision speaks directly to the reproductive rights of women receiving assistance, we might expect that states who are more restrictive in their TANF policies are more likely to restrict the reproductive rights of women as well.

Additionally, in their study of welfare reform sanctions, Soss et al. (2001) posited that welfare sanctions under TANF might be explained by measuring the degree to which a state experiences party competition. Grounded in the work of V.O. Key (1949), states in which political parties are more competitive, parties are more likely to adopt more liberal social policies as a means to appeal to a broader base of voters. More recent work by Holbrook and Van Duck (1993) and Brace and Jewett (1995) has lent support to Key's original hypothesis. Because reproductive rights for women 
tend to fall toward the liberal side of the policy spectrum, we would expect that states with higher levels of inter-party competition will tend to have less restrictive reproductive policies than states with lower levels of competition. An interesting question is the degree to which this hypothesis might modify the effects of government ideology. In Virginia, for example, party competition is relatively high, but the state (as a whole) tends toward the conservative side of the ideological spectrum. The state legislature has been dominated for many years by more conservative representatives from the state's more rural western and southern districts.

\section{The Hypothesized Impact of Political Variables}

Based on the above arguments, the political variables examined are the percentage of women in the state legislature, the relative strength of the Democratic and Republican parties of a state as determined by political party control of the legislature and Governor's office, the government ideology of the state, the degree of inter-party competition, and the degree to which the state restricts Temporary Aid to Needy Families (TANF). It is expected that the more Democrats in office, the more inter-party competition there is, and the more women there are in a state legislature, the less restrictive the state's policies will be towards reproductive healthcare. A positive correlation is expected between the restrictiveness a state's TANF policy, a conservative government ideology, and the restrictiveness of that state's policies towards reproductive healthcare.

$\boldsymbol{H}_{8}:$ The more restrictive a state is towards its TANF policy, the more restrictive that state will be towards reproductive healthcare.

$\boldsymbol{H}_{9:}$ If Democrats hold a majority in the state house, the less restrictive a state will be towards reproductive healthcare.

$\boldsymbol{H}_{10}$ : If the Governor is a Democrat, the less restrictive a state will be towards reproductive healthcare.

$\boldsymbol{H}_{11}$ : States with more conservative government ideology scores will be more likely to enact more restrictive reproductive healthcare policies.

$\boldsymbol{H}_{12}$ : The higher the percentage of women in the state legislature, the less restrictive a state will be towards reproductive healthcare. $\boldsymbol{H}_{13}$ : States with higher levels of inter-party competition will be more likely to have less restrictive reproductive healthcare policies.

In sum, states have become the battleground where abortion policy is played out since the Webster and Casey decisions shifted more power to state legislatures. This study reflects that shift and uses states as the unit of 
analysis. Furthermore, we expand upon previous studies by examining broader reproductive rights policy. See the appendix for a compilation of the data sources used for this research project.

\section{Methods}

To test these hypotheses, several multiple regressions were performed using SPSS Version 16.0 for Windows between a state's likeliness to enact restrictive policies towards reproductive healthcare and three explanatory models examining the influence of religious, socioeconomic, and political variables. In a fourth model, we construct a model of "best fit" to explain variations in state reproductive health policy.

The dependent variable is an interval score of state restrictiveness on reproductive healthcare policies, ranging from the least restrictive (-90) to the most restrictive (148). In order to make the analyses more straightforward, the scores were transformed so that the least restrictive state is scored as " 1 " and the most restrictive state is given a value of 239. Our explanatory variables are measured at various scales; therefore we report standardized coefficients in our results.

All data were screened and fully vetted to conform to multivariate regression assumptions. Two observations were not included in our models owing to missing data. While not included in the tables presented here, all models were reexamined including the missing observations by using an average value for the respective missing data. The results did not materially affect the findings.

\section{Results and Discussion}

\section{Religion Variables}

Our first model examines the effects of religion on a state's policy restrictiveness for access to reproductive healthcare (Table 2). The percentages of Evangelical and Jewish populations were found to be significant. The model representing the religious explanation had an adjusted R-squared value of .268. The percentage of the Catholic population was not significant but the relationship was in the hypothesized direction. That the percent of the population that is Catholic is not seen to be significant is contrary to the bulk of the extant literature, but seems to correspond with Sullins' (1999) study that reported a decline in pro-choice attitudes in younger Protestants and a "clear pro-choice trend among younger Catholics" with the difference largely being attributed to church attendance-church attendance has decreased among younger Catholics (Jelen and Wilcox 2003, 492). 


\section{Table 2. Competing Models Explaining State Restrictiveness in Reproductive Healthcare Policies}

\begin{tabular}{|c|c|c|c|}
\hline & $\begin{array}{c}\text { Religious } \\
\text { Model } 1\end{array}$ & $\begin{array}{l}\text { Socioeconomic } \\
\text { Model } 2\end{array}$ & $\begin{array}{l}\text { Political } \\
\text { Model } 3\end{array}$ \\
\hline Percent Catholic & .213 & & \\
\hline Percent Jewish & $-.302 *$ & & \\
\hline Percent Evangelical & $.498 * *$ & & \\
\hline Percent African American & & .164 & \\
\hline Percent Hispanic & & -.253 & \\
\hline Per Capita Income & & $-.526 * * *$ & \\
\hline Percent Urban & & .152 & \\
\hline Percent Female Legislators & & & $-.537 * * *$ \\
\hline Democratic Governor & & & -.058 \\
\hline Democratic House & & & $-.256^{*}$ \\
\hline TANF Restrictiveness & & & -.158 \\
\hline InterParty Competition & & & -.085 \\
\hline Government Ideology & & & -.096 \\
\hline $\mathrm{N}$ & 48 & 48 & 48 \\
\hline Adj $R^{2}$ & .268 & .312 & .483 \\
\hline$*<.05 ; * *<.01 ; * * *<.001$ & & & \\
\hline
\end{tabular}

Traditionally, the American Catholic church has taken a more liberal approach on matters of reproductive rights than has the church in Rome. While it remains for future testing to confirm or deny this point, we suspect that our findings in regards to Catholics and reproductive rights are a result of this schism. The Roman Catholic Church has taken a strong stance against abortion and access to birth control, but it is likely that American Catholics are split on this stance, which would in turn weaken the effect of the Catholic population in this policy realm. On the other hand, no such schisms exist between different Jewish sects or Evangelical churches, thus strengthening the relative impacts of these populations on state policy decisions.

\section{Socio-Economic Variables}

Of the four socio-economic variables, only per capita income is statistically significant and also in the hypothesized directional relationship. The socioeconomic model has an adjusted R-square of .312. Our hypothesis for per capita income is supported.

Race and metropolitan population are hypothesized to have a negative relationship with the state's level of restrictiveness towards reproductive healthcare. These hypotheses are not supported by the model. Both percent 
black and metropolitan populations have positive, though statistically insignificant, relationships toward the reproductive healthcare policies of a state. However, the Hispanic variable did have a relationship in the hypothesized direction, though it was not statistically significant. The positive relationship found between race and restrictiveness support Jelen and Wilcox's (2003) finding of an emergent race gap between blacks and whites with regard to support for abortion. Indeed, it appears from our findings that the race gap expands well beyond abortion to all forms of reproductive healthcare.

\section{Political Variables}

All six political variables are directionally consistent with our hypotheses, but only Democratic control of the legislature and percent of women legislators were found to be significant. The political model yields an adjusted R-square value of .483. This outcome echoes an earlier finding by Strickland and Whicker (1992), who compared socioeconomic independent variables to political independent variables and found Democratic and Republican representation levels to affect state restrictiveness towards abortion. However, overall their results suggested that socioeconomic variables explain more variance of state restrictiveness towards abortion than did political variables. The party that controls the governor's mansion is not a factor in this policy realm, although party control of the legislature is a reasonable predictor of the level of a state's restrictiveness. Thus, only two of our six hypotheses are supported in this model.

Surprisingly, our measure of TANF restrictiveness did not prove to be a significant predictor of our dependent variable. Although the sign was in the predicted direction, these two policy decisions seem to have little in common. The most notable finding is the dominating impact of percent of women in the legislature on state policy towards reproductive healthcare, which supports both previous literature and conventional wisdom. Clearly, states with larger numbers of women in the legislature are more likely to support greater access to reproductive healthcare; this variable was the strongest predictor of all the variables tested in the models. Female legislators have a personal vested interest in women's health issues, and this interest clearly extends into the policy decisions of states in this area. We also tested the interactive effects of the percentage of female legislators and party control of the legislature, to determine whether the effect was driven more by party effects than gender effects. The interactive term was in the expected direction but not statistically significant $(p=.057)$. We conclude that gender is the driving factor; the gender effect can be enhanced slightly by party identification, but gender matters more than party. Because we initially 
hypothesized that gender would be the controlling factor, we omitted the interactive term from the model in favor of the separate variables.

\section{A Revised Model of State Restrictiveness}

The three models presented in the preceding section provide us with a good indication of the relative explanatory power of each set of factors on state restrictiveness. Our next step, however, is to combine the three explanations in a quest for a model of "best fit." Table 3 presents a model of best fit for exploring variation in state restrictiveness.

Our revised model yields an adjusted R-squared value of .557, a notable improvement over the best of our previous models. As we might expect, the percent of women in the legislature is once again the single most powerful explanatory in the model, underscoring the role these legislators play in securing access to reproductive healthcare for women. Another political indicator, a dummy variable indicating whether or not the majority of a State's house are Democrats, significantly contributes to the model. Again, this is consistent with the stated political platform of the party, which continues to support access to abortion, as well as access to other forms of reproductive health care. The third major contributor to explaining the model is per capita income, a finding consistent with previous studies that examined only access to abortion.

\section{Table 3. A Revised Model of State Restrictiveness}

\begin{tabular}{lc}
\hline Per Capita Income & $-.313^{* *}$ \\
Percent Female Legislators & $-.470^{* * *}$ \\
Democratic House & $-.292^{* *}$ \\
$\mathrm{~N}$ & 48 \\
Adj $\mathrm{R}^{2}$ & .557 \\
$*<.05 ; * *<.01 ; * * *<.001$ & \\
\hline
\end{tabular}

\section{Conclusion}

This analysis fills a gap in the literature by modeling a variety of factors that affect a state's reproductive healthcare policies. Previous studies have analyzed some of these variables, but not within the comprehensive framework provided here. Additionally, previous studies only analyzed abortion policy and not the wide-ranging area of reproductive healthcare in general. In short, this analysis captures a broader representation of 
reproductive healthcare and provides a more holistic examination, including aspects like contraception access and state self-conscience clauses; aspects which go beyond just abortion access to cover a state's tendencies towards reproductive healthcare as a whole.

Concomitant with these issues are state spousal or parental notification requirements - not just for abortion, but for other reproductive health issues as well. This study thus provides a broader and more realistic view of abortion and reproductive rights than does much of the existing literature. To that end, we find that while some of the models that provide explanatory power for abortion also provide some explanatory power here, they manifest themselves somewhat differently when applied to a broader measure of reproductive rights.

Perhaps the finding that most calls for additional research is the effect of religion, particularly Catholicism, on reproductive rights. While we believe our results are indicative of a broader split between American Catholics and the Vatican, further research is needed to better comprehend the dynamic at work with this variable. Likewise, we find the lack of significance for party control of the governor's mansion somewhat surprising; perhaps a future analysis that controls for "strong" governors/"weak" governors might be instructive.

Another area for further analysis is the relationship between a state's stance on reproductive healthcare and other policy areas that directly affect rights for women. In areas such as environmental policy, for example, there is generally a high correlation between a state's willingness to enforce both air pollution and water pollution statutes, for example (see Dryzek and Lester 1989; Ringquist 1993). Perhaps the similarities between different pollution media are clearer in the minds of state policy makers than are the similarities in policies that restrict personal behaviors, but this is an area that clearly requires additional study and testing.

Indeed, there are many different explanations for state policy choices that are ripe for testing. Unexplored in this study, for example, are measures of citizen ideology, legislator ideology, turnout of women in recent elections, regionalism, and state political culture, among many others. It is likely that some of these alternative explanations will add additional predictive power to our models; these alternative explanations are the subject of future research. 


\section{APPENDIX}

The following data sources were used to compile the variables:

Percent Urban - Source: Census Bureau's March 2006 and 2007 Current Population Survey (CPS: Annual Social and Economic Supplements).

Race/Ethnicity - Source: same as Percent Urban.

Temporary Assistance to Needy Families (TANF) restrictions - Source: Soss et al. (2001).

Per Capita Income - Source: Bureau of Economic Analysis, U.S. Department of Commerce, 2005 revised.

Religion (Percent Catholic) - Source: Glenmary Research Center. Based on 2000 numbers.

Religion (Percent Evangelical) - Source: Association of Religion Data Archives. Based on 2000 numbers.

Religion (Percent Jewish) - Source: Mandell L. Berman Institute North American Jewish Data Bank's American Jewish Yearbook.

Women Legislators - Source: The National Conference of State Legislatures based on 2005 information.

Political Party in Governor's Office - Source: The National Conference of State Legislatures based on 2005 information.

Political Party in Control of a State's House and Senate - Source: National Conference of State Legislatures based on 2005 information.

State Restrictions on Reproductive Healthcare - Source: NARAL, 2006 Report Card.

Inter-party Competition - Berry, et al. (1996)

Government Ideology - Soss, et al. (2001), who calculated an index with data drawn from the U.S. Census (1998).

\section{REFERENCES}

Baker, Ross K., Laurily K. Epstein, and Rodney D. Forth. 1981. Matters of Life and Death: Social, Political and Religious Correlates of Attitudes on Abortion. American Politics Quarterly 9:89-102.

Berkman, M.B., and R.E. O'Conner. 1993. Do Women Legislators Matter? Female Legislators and State Abortion Policy. American Politics Research 21:102-124.

Berry, William D., Evan Ringquist, Richard Fording, and Russell Hanson. 1998. Measuring Citizen and Government Ideology in the American States, 1960-1993. American Journal of Politics 42:327-348.

Blake, Judith, and Jorge H. Del Pinal. 1981. Negativism, Equivocation and Wobbly Assent: Public 'Support' for the Pro-Choice Platform on Abortion. Demography 18:309-320.

Brace, Paul, and Aubrey Jewett. 1995. The State of State Politics Research. Political Research Quarterly 48:643-681.

Byrnes, Timothy A., and Mary C. Segers, eds. 1992. The Catholic Church and the Politics of Abortion: A View from the States. Boulder, CO: Westview Press.

Caiazza, Amy. 2004. Does Women's Representation in Elected Office Lead to WomenFriendly Policy? Analysis of State-Level Data. Women \& Politics 26:35-70. 
Centers for Disease Control and Prevention. 2000. Abortion Surveillance-United States. Washington, DC: U.S. Government Printing Office.

Conway, Karen Smith, and Michael R. Butler. 1992. State Abortion Legislation as a Public Good-Before and After Roe v. Wade. Economic Inquiry 30:609-626.

Cook, Elizabeth A., Ted G. Jelen, and Clyde Wilcox. 1993. Catholicism and Abortion Attitudes in the American States: A Contextual Analysis. Journal for the Scientific Study of Religion 32:375-83.

Dryzek, John S., and James P. Lester. 1989. Alternative Views of the Environmental Problematic. In Environmental Politics and Policy: Theories and Evidence, ed. James P. Lester. Durham, NC: Duke University Press.

Evans, John H. 2002. Polarization in Abortion Attitudes in U.S. Religious Traditions, 1972-1998. Sociological Forum 17:397-422.

Gohmann, Stephan F., and Robert L. Ohsfeldt. 1994. Which States Will Restrict Abortions? Predictions from Votes in the House of Representatives. Policy Studies Review 13:19-38.

Haas-Wilson, D. 1996. The Impact of State Abortion Restrictions on Minors' Demand for Abortion. Journal of Human Resources 31(1):140-158.

Hansen, Susan B. 1980. State Implementation of Supreme Court Decisions: Abortion Rates Since Roe v Wade. Journal of Politics 42:372-395.

Heft, James L. 2005. U.S. Catholics and the Presidential Election: Abortion and Proportionate Reasons. New Blackfriars 86:259-275.

Holbrook, Thomas M., and Emily Van Dunk. 1993. Electoral Competition in the American States. American Political Science Review 87:955-962.

Jelen, Ted G., and Clyde Wilcox. 2003. Causes and Consequences of Public Attitudes toward Abortion: A Review and Research Agenda. Political Research Quarterly 56:489-500.

Kahane, Leo H. 1994. Political, Ideological, and Economic Determinants of Abortion Position: An Empirical Analysis of State Legislatures and Governors. American Journal of Economics and Sociology 53:347-360.

Key, V.O. 1949. Southern Politics in State and Nation. New York: Knopf.

Legge, J. 1983. The Determinants of Attitudes toward Abortion in the American Electorate. Western Political Quarterly 36(3):479-490.

Medoff, Marshall. 2002. The Determinants and Impact of State Abortion Restrictions. American Journal of Economics and Sociology 61:481-493.

Medoff, Marshall H., Christopher Dennis, and B.G. Bishin. 1995. Bimodal Issues, the Median Voter Model, Legislator's Ideology, and Abortion. Atlantic Economic Journal 23:293-303.

National Abortion Rights Action League. 2006. Who Decides? The Status of Women's Reproductive Rights in the United States, 15th ed. Washington, DC: National Abortion Rights Action League.

Norrander, Barbara, and Clyde Wilcox. 1999. Public Opinion and Policymaking in the States: The Case of Post-Roe Abortion Policy. Policy Studies Journal 27:707-722.

Oakley, Maureen Rand. 2003. Abortion Restrictions and Abortion Rates: Has State Abortion Policy Been Successful? Politics and Policy 31:472-487.

Open Letter To Those Who Would Outlaw Abortion. 1989. The New York Times, Feb. 28.

Peterson, Larry R. 2001. Religion, Plausibility Structures, and Education's Effects on Attitudes toward Abortion. Journal for the Scientific Study of Religion 40:187-204.

Planned Parenthood of Southeastern Pennsylvania v. Casey. 1992. 505 US 833. 
Ringquist, Evan J. 1993. Environmental Protection at the State Level: Politics and Progress in Controlling Pollution. Armonk, NY: M.E. Sharp.

Schecter, D. 2001. What Drives the Voting on Abortion Policy? Investigating Partisanship and Religion in the State Legislative Arena. Women \& Politics 3:61-84.

Soss, Joe, Sanford F. Schram, Thomas P. Vartanian, and Erin O'Brien. 2001. Setting the Terms of Relief: Explaining State Policy Choices in the Devolution Revolution. American Journal of Political Science 45:378-395.

Strickland, Ruth Ann, and Marcia Lynn Whicker. 1992. Political and Socioeconomic Indicators of State Restrictiveness Toward Abortion. Policy Studies Journal 20:598-617.

Strickler, Jennifer, and Nicholas L. Danigelis. 2002. Changing Frameworks in Attitudes Toward Abortion. Sociological Forum 17:187-201.

Sullins, D. Paul. 1999. Catholic/Protestant Trends on Abortion: Convergence and Polarity. Journal for the Scientific Study of Religion 38:354-69.

Tedrow, Lucky M., and E.R. Mahoney. 1979. Trends in Attitudes towards Abortion: 1972-1976. Public Opinion Quarterly 43:181-89.

The Alan Guttmacher Institute. 2008. Facts on Induced Abortion in the U.S. In brief (January). Available at http://www.guttmacher.org/pubs/fb induced_abortion.html.

U.S. Census Bureau. 1998. Statistical Abstract of the United States. Washington, DC: U.S. Government Printing Office.

Webster v. Reproductive Health Services. 1989. 492 US 490.

Wetstein, Matthew E., and Robert B. Albritton. 1995. Effects of Public Opinion on Abortion Policies and Use in the American States. Publius 25:91-105. 